\title{
PENGARUH GAYA KEPEMIMPINAN DAN MOTIVASI KERJA TERHADAP KEPUASAN KERJA KARYAWAN (Studi Kasus Pada PT Inovasi Teknologi)
}

\author{
Happy Darmawan \\ Fakultas Ekonomi Universitas Tarumanagara \\ Email:happy_darmawan@yahoo.com
}

\begin{abstract}
The purpose of this study was to identify and analyze the influence of motivation kerjaterhadap leadership style and job satisfaction of employees at PT Technological Innovation. This research was conducted by tekknik simple random sampling (simple sampling technique), with a sample of 75 respondents. Entire multiple regression equation used meets the requirements of the classical assumption test. The results of this study indicate that there is a significant and positive influence between leadership style and motivation simultaneously on employee job satisfaction in PT Technological Innovation.
\end{abstract}

Keywords: leadership style, employee motivation, satisfaction, performance

\begin{abstract}
Abstrak: Tujuan penelitian ini adalah untuk mengetahui dan menganalisa pengaruh gaya kepemimpinan dan motivasi kerjaterhadap kepuasan kerja karyawan pada PT Inovasi Teknologi. Penelitian ini dilakukan dengan tekknik simple random sampling (teknik sampel sederhana), dengan sampel sebanyak 75 responden. Seluruh persamaan regresi ganda yang digunakan telah memenuhi persyaratan uji asumsi klasik. Hasil dari penelitian ini menunjukkan bahwa terdapat pengaruh yang signifikan dan positif antara gaya kepemimpinan dan motivasi secara simultan terhadap kepuasan kerja karyawan di PT Inovasi Teknologi.
\end{abstract}

Kata kunci: Gaya kepemimpinan, motivasi kerja, kepuasan, kinerja

\section{PENDAHULUAN}

Kelangsungan hidup dan pertumbuhan dari suatu perusahaan bukan hanya ditentukan dari keberhasilan dalam mengelola keuangan, pemasaran serta produknya, tetapi juga ditentukan dari keberhasilan mengelola sumber daya manusia. Saat ini sumber daya manusia dianggap sebagai sumber daya yang penting bagi organisasi, karena tanpa sumber daya manusia dalam organisasi bukan hal yang mudah karena melibatkan berbagai elemen dalam sebuah organisasi, yaitu karyawan,pimpinan, maupun sistem itu sendiri. Perpaduan antara ketiga hal tersebut diharapkan mampu memunculkan lingkungan kerja yang kondusif sehingga baik karyawan maupun pimpinan dapat melaksanakan pekerjaannya secara maksimal. Bagi karyawan, lingkungan kerja yang kondusif tersebut diharapkan mampu menciptakan kepuasan kerja. Kepuasan kerja mempunyai pengaruh terhadap produktivitas organisasi baik secara langsung maupun tidak langsung. Ketidakpuasan merupakan titik awal dari masalah-masalah yang muncul dalam organisasi seperti kemangkiran, konflik manager-pekerja dan perputaran karyawan. Dari sisi pekerja, 
ketidakpuasan dapat menyebabkan menurunnya motivasi, menurunnya moril kerja, dan menurunnya tampilan kerja baik secara kualitatif maupun secara kuantitatif.

Pengukuran kinerja suatu organisasi adalah sangat penting bagi pimpinan sebagai top manajer, guna mengevaluasi dan perencanaan masa depan. Beberapa jenis informasi yang digunakan dalam pengendalian disiapkan dalam rangka menjamin bahwa pekerjaan yang dilakukan telah dilakukan secara efektif dan efisien. Manajer dalam menjalankan tugas sehari-hari akan menggunakan orang lain dalam operasional organisasi, orang lain tersebut dalam hal ini adalah pegawainya yang harus diukur kinerjanya.

Dalam melaksanakan aktivitas kegiatannya para pemimpin mempunyai berbagai gaya tersendiri dalam proses mempengaruhi dan mengarahkan karyawannya, sehingga nantinya mau bersama-sama berusaha mencapai tujuan dari perusahaan bervariasi, maka para pemimpin dituntut untuk mampu menerapkan gaya kepemimpinan yang bervariasi pula sesuai dengan tujuan yang dihadapi.oleh karena itu pemimpin akan berusaha seefektif mungkin di dalam kepemimpinannya sehingga dapat mencapai sasaran dari kelompok ataupun organisasi secara maksimal. Apabila gaya kepemimpinan yang digunakan sesuai dengan karyawan makan akan memberikan kepuasan kerja bagi karyawannya

Kinerja pegawai akan lebih baik apabila yang bersangkutan memiliki keahlian (skill) dan bersedia bekerja karena digaji sesuai dengan jenjangnya dan adanya harapan (expectation) yang lebih baik di masa yang akan datang. Adanya harapan tersebut merupakan salah satu motivasi yang kuat bagi pegawai untuk melaksanakan kerja dengan kinerja yang baik. Motivasi menurut Gibson (2001:94) adalah konsep yang menguraikan tentang kekuatan-kekuatan yang ada dalam diri karyawan yang memulai mengarahkan perilaku. Seseorang yang sangat termotivasi, yaitu orang yang melaksanakan upaya substansial, guna menunjang produktivitas dalam bekerja. Sebaliknya,jika seseorang yang bermotivasi rendah umumnya akan melakukan upaya minimal dalam bekerja. Apabila pegawai dengan pimpinan memiliki kinerja yang baik akan berdampak pada kinerja organisasi tempat mengabdi.

Peningkatan kepuasan kerja karyawan pada suatu organisasi tidak bisa dilepaskan dari peranan pemimpin dalam organisasi tersebut. Kepemimpinan merupakan kunci utama dalam manajemen yang memainkan peran penting dan strategis dalam kelangsungan hidup suatu perusahaan. Pemimpin merupakan pencetus tujuan, merencanakan, mengorganisasikan, menggerakkan dan mengendalikan seluruh sumber daya yang dimiliki sehingga tujuan perusahaan dapat tercapai secara efektif dan efisien. Oleh sebab itu pemimpin suatu perusahaan dituntut untuk selalu mampu menciptakan kondisi yang mampu memuaskan karyawan dalam bekerja sehingga diperoleh karyawan yang tidak hanya mampu bekerja akan tetapi juga bersedia bekerja kearah pencapaian tujuan persuahaan. Seorang pemimpin harus mengambil keputusan yang sangat besar terhadap suatu permasalahan. Keputusan yang menyangkut perubahan besar pada strategi organisasi atau politik, kebanyakan hasilnya akan tergantung pada ketrampilan mempengaruhi dan ketekunan para individu manajer yang ingin memprakarsai perubahan dan pada kekuasaan relatif dari berbagai koalisi yang tersangkut dalam membuat atau memberi wewenang untuk membuat keputusan tersebut.

Tuntutan globalisasi telah menyadarkan pelaku bisnis mengenai pentingnya sumber daya manusia yang berkualitas, baik para pemimpin maupun bawahannya. Peran pemimpin sangat diperlukan dalam usaha menetapkan tujuan. Organisasi tidak akan berhasil tanpa adanya peran serta dari karyawan. Kedua hal tersebut berjalana beriringan 
walaupun memiliki tujuannya masing-masing, karyawan tentu akan merasa puas apabila kebutuhan dan keinginannya terpenuhi.

Permasalahan dalam penelitianini adalah: (1) Apakah terdapat pengaruh gaya kepemimpinan terhadap kepuasan kerja karyawan pada PT Inovasi Teknologi; (2) Apakah terdapat pengaruh motivasi kerja terhadap kepuasan kerja karyawan pada PT Inovasi Teknologi;(3) Apakah terdapat pengaruh gaya kepemimpinan dan motivasi kerja secara bersama-sama terhadap kepuasan kerja karyawan pada PT Inovasi Teknologi.

Tujuan dalam penelitian ini antara lain: (1) Untuk mengetahui pengaruh pada gaya kepemimpinan terhadap kepuasan kerja karyawan pada PT Inovasi Teknologi; (2) Untuk mengetahui pengaruh ada motivasi kerja terhadap kepuasan kerja karyawan pada PT Inovasi Teknologi; (3) Untuk mengetahui pengaruh pada gaya kepemimpinan dan motivasi kerja secara bersama-sama terhadap kepuasan kerja karyawan pada PT Inovasi Teknologi.

\section{KAJIAN TEORI}

Kepemimpinan. Dubrin (2005:3) mengemukakan bahwa kepemimpinan itu adalah upaya mempengaruhi banyak orang melalui komunikasi untuk mencapai tujuan, cara mempengaruhi orang dengan petunjuk atau perintah, tindakan yang menyebabkan orang lain bertindak atau merespons dan menimbulkan perubahan positif, kekuatan dinamis penting yang memotivasi dan mengkoordinasikan organisasi dalam rangka mencapai tujuan, kemampuan untuk menciptakan rasa percaya diri dan dukungan diantara bawahan agar tujuan organisasional dapat tercapai.

Menurut Nawawi (2008:229) kepemimpinan adalah suatu kemampuan untuk menggerakkan atau memotivasi anggota organisasi agar secara serentak melakukan kegiatan yang sama dan terarah dalam pencapaian tujuannya. Kepemimpinan juga merupakan aspek penting dalam mengelola organisasi karena kemampuan memimpin merupakan salah satu kunci untuk menjadi manajer yang baik. Sebaliknya para manajer perlu berusaha untuk menjalankan dasar-dasar kepemimpinan agar menjadi pemimpin yang efektif (Nawawi, 2008: 230). Nimran (2004:64) mengemukakan bahwa kepemimpinan atau leadership adalah merupakan suatu proses mempengaruhi perilaku orang lain agar berperilaku seperti apa yang dikehendaki.

Mintzberg dalam luthans (2002) dan sutiadi (2003:4) mengemukakan bahwa peran kepemimpinan dalam organisasi adalah sebagai pengatur visi, motivator, penganalisis, dan pengusaan pekerjaan. Yasin (2001:6) mengemukakan bahwa keberhasilan kegiatan usaha pengembangan organisasi, sebagaian besar ditentukan oleh kualitas kepemimpinan atau pengelolanya dan komitmen pimpinan puncak organisasi untuk investasi energi yang diperlukan maupun usaha-usaha pribadi pimpinan.

Sedangkan menurut Suryadhana(2011) kepemimpinan merupakan kemampuan atasan untuk menggerakkan dan mengarahkan bawahannya dalam mencapai tujuan yang diharapkan. Seorang pemimpin dituntut untuk dapat mengendalikan bawahannya agar dapat melaksanakan tugas sesuai dengan bidangnya.

Motivasi. Motivasi merupakan masalah kompleks dalam organisasi, karena kebutuhan dan keinginan setiap anggota organisasi berbeda satu dengan yang lainnya. Hal ini berbeda karena setiap anggota suatu organisasi adalah unik. Secara biologis maupun psikologis, dan berkembang atas dasar proses belajar yang berbeda pula (Suprihanto dkk, 2003:41). 
Motivasi menurut Anoraga (2005) dalam Purwati (2009) adalah kebutuhan yang mendorong perbuatan untuk suatu tujuan tertentu. Jadi motivasi kerja adalah sesuatu yang menimbulkan semangat atau dorongan kerja. Sedangkan menurut Robbins (2002:225) adalah kesediaan melakukan usaha tingkat tinggi guna mencapai sasaran organisasi, yang dikondisikan oleh kemampuan usaha tersebut memuaskan kebutuhan sejumlah individu.

Luthans (dalam Safaria, 2004) motivasi diartikan sebagai sebuah proses yang dimulai dari adanya kekurangan baik secara fisiologis maupun psikologis yang memunculkan perilaku atau dorongan yang diarahkan untuk mencapai sebuah tujuan yang spesifik atau insentif. Berdasarkan pendapat para ahli di atas, dapat disimpulkan bahwa motif merupakan suatu dorongan, kebutuhan dalam diri pegawai yang perlu dipenuhi agar pegawai tersebut dapat menyesuaikan diri terhadap lingkungannya, sedangkan motivasi adalah kondisi yang menggerakan pegawai agar mampu mencapai tujuan dan motifnya. Sedangkan motivasi dikatakan sebagai energi untuk membangkitkan dorongan dalam diri (drive arousal). Dalam hubungannya dengan lingkungan kerja, Ernest L. Mc Cormick (dalam Mangkunegara, 2002:94) mengemukakan bahwa motivasi kerja didefinisikan sebagai kondisi yang berpengaruh membangkitkan, mengarahkan dan memelihara perilaku yang berhubungan dengan lingkungan kerja.

Siagian (2002: 94) mengemukakan bahwa dalam kehidupan berorganisasi, termasuk kehidupan berkarya dalam organisasi bisnis, aspek motivasi kerja mutlak mendapat perhatian serius dari para manajer. Karena 4 (empat) pertimbangan utama yaitu: (1) Filsafat hidup manusia berkisar pada prinsip "quit pro quo", yang dalam bahasa awam dicerminkan oleh pepatah yang mengatakan " ada ubi ada talas, ada budi ada balas ", (2) Dinamika kebutuhan masusia sangat kompleks dan tidak hanya bersifat materi, akan tetapi juga bersifat psikologis, (3) tidak ada titik jenuh dalam pemuasan kebutuhan manusia, (4) Perbedaan karakteristik individu dalam organisasi atau perusahaan, mengakibatkan tidak ada nya satupun tektik motivasi yang sama efektifnya untuk semua orang dalam organisasi juga ntuk seseorang pada waktu dan kondisi yang berbeda-beda.

Pengertian Kepuasan Kerja. Werther dan Davis (1986) mengemukakan bahwa kepuasan kerja adalah kondisi kesukaan atau ketidaksukaan menurut pandangan karyawan terhadap pekerjaannya. Dole dan Schroeder (2001) dalam koesmono (2005), mengemukakan bahwa kepuasan kerja dapat didefinisikan sebagai perasaan dan reaksi individu terhadap lingkungan pekerjaannya. Lebih lanjut Koesmono (2005) mengemukakan bahwa kepuasan kerja merupakan penilaian, perasaan atau sikap seseorang atau karyawan terhadap pekerjaan atau sikap seseorang atau karyawan terhadap pekerjaannya dan berhubungan dengan lingkungan kerja, jenis pekerjaan, kompensasi, hubungan antar teman kerja, hubungan social ditempat kerja dan sebagainya.

Sehingga dapat dikatakan bahwa kepuasan kerja adalah dipenuhinya beberapa keinginan dan kebutuhannya melalui kegiatan kerja atau bekerja.

Teori-Teori Kepemimpinan. Dalam Mulyadi dan Rivai ( 2009 ) dikemukakan beberapa teori kepemimpinan, yaitu: Pertama. Teori Sifat. Teori ini memandang pemimpin sebagai suatu kombinasi sifat-sifat yang tampak dari pemimpin. Adapun sifat atau karakteristik, dan kemampuan yang luar biasa yang dimiliki seorang pemimpin, antara lain: (a) Inteligensia; (b) Kepribadian; (c) Karakteristik fisik.

Kedua. Teori Perilaku. Dalam teori ini perilaku pemimpin merupakan sesuatu yang bisa dipelajari. Teori ini memusatkan perhatiannya pada dua aspek perilaku kepemimpinan, 
yaitu: fungsi kepemimpinan, dan gaya kepemimpinan.Terdapat dua fungsi kepemimpinan, yaitu: (a) Fungsi yang berorientasi tugas; (b)Fungsi yang berorientasi orang atau pemeliharaan kelompok (sosial). Ketiga. Teori Situasional. Merupakan suatu pendekatan terhadap kepemimpinan yang menyatakan bahwa pimpinan memahami perilakunya, sifatsifat bawahannya, dan situasi sebelum menggunakan suatu gaya kepemimpinan tertentu. Pendekatan ataupun teori ini mensyaratkan pemimpin untuk memiliki keterampilan diagnostic dalam perilaku manusia.

Macam-macam gaya kepemimpinan, menurut Robbins (2006) terdapat empat macam gaya kepemimpinan yaitu sebagai berikut: (a) Gaya kepemimpinan kharismatik. adalah gaya kepemimpinan yang memicu para pengikutnya dengan memperlihatkan kemampuan heroic atau luar biasa ketika mereka mengamati perilaku tertentu pemimpin mereka; (b) Gaya kepemimpinan transaksional, yaitu gaya kepemimpinan yang memandu atau memotivasi para pengikutnya menuju ke sasaran yang ditetapkan dengan memperjelas persyaratan peran dan tugas; (c) Gaya kepemimpinan transformasional. Ialah gaya kepemimpinan yang menginspirasi para pengikut untuk melampaui kepentingan pribadi mereka dan mampu membawa dampak yang mendalam dan luar biasa pada pribadi para pengikutnya; (d) Gaya kepemimpinan visioner. Merupakan gaya kepemimpinan yang mampu menciptakan dan mengartikulasikan visi yang realistis, kredibel, dan menarik mengenai masa depan organisasi atau unit organisasi yang tengah tumbuh dan membaik.

Motivasi Kerja. Motivasi berasal dari kata dasar motif (motive) dapat diartikan sebagai dorongan, sebab atau alas an seseorang melakukan sesuatu. Dengan demikian motivasi berarti suatu kondisi yang mendorong atau menjadi sebab seseorang melakukan suatu perbuatan yang berlangsung secara sadar (Nawawi, 2008:350).

Menurut nawawi, (2008, 351) terdapat enam teori motivasi yang dapat diimplementasikan dalam manajemen SDM di lingkungan suatu organisasi, yaitu: (1) Teori kebutuhan (need) dari Abraham maslow; (2) Teori dua faktor dari Frederick Herzberg; (3) Teori prestasi (achievement )dari David Mc Clelland;(4) Teori penguatan (reinforcement); (5) Teori harapan ( expectancy); (6) Teori tujuan sebagai investasi

Tiga teori yang disebut pertama berfokus pada apa yang mendorong manusia melakukan suatu tujuan kegiatan. Teori tersebut membahas tentang suatu sesuatu yang mendorong ( motivator ) seseorang dalam melakukan suatu kegiatan. Oleh karena itu teori-teori tersebut dikelompokkan dalam kategori " teori isi (content theories). Selanjutnya tiga teori yang disebutkan terakhir adalah teori-teori motivasi yang berfokus pada bagaimana mendorong manusia agar berbuat sesuatu. Termasuk juga dalam bekerja disebuah organisasi. Dengan demikian berarti teori-teori motivasi tersebut membahas cara-cara dan langkah-langkah dalam memberikan dorongan, sehingga dikategorikan sebagai " teori proses "

Kepuasan Kerja. Menurut Umam (2010:194) banyak faktor yang menentukan kepuasan kerja, diantaranya adalah gaji, kondisi kerja dan hubungan kerja. Gaji/imbalan yang dirasakan adil. Kepuasan kerja merupakan fungsi dari jumlah absolut dari gaji yang diterima, sejauhmana gaji memenuhi harapan-harapan tenaga kerja, dan bagaimana gaji diberikan. Kondisi kerja yang menunjang. Ruangan kerja yang sempit, panas, cahaya lampu yang menyilaukan mata, akan dapat menimbulkan ketidaknyamanan dalam bekerja. Dengan demikian, perusahaan harus menyediakan ruang kerja yang terang, sejuk dengan peralatan kerja yang nyaman untuk digunakan. Kebutuhan-kebutuhan fisik yang terpenuhi akan memuaskan tenaga kerja. 
Hubungan kerja (rekan kerja dan atasan): (1) Hubungan kerja dengan rekan kerja. Kepuasan kerja yang ada pada para karyawan timbul karena kebutuhan-kebutuhan tingkat tinggi para karyawan terpenuhi seperti kebutuhan harga diri, dan kebutuhan aktualisasi diri; (2) Hubungan kerja dengan atasan. Kepemimpinan yang konsisten berkaitan dengan kepuasan kerja adalah tenggang rasa. Hubungan fungsional mencerminkan sejauhmana atasan membantu karyawan untuk memuaskan nilai-nilai pekerjaan yang penting bagi mereka; (3) Hubungan kerja dengan bawahan. Atasan memliki ciri memimpin yang transformasial, dapat mendorong karyawan untuk meningkatkan motivasinya dan sekaligus merasa puas dengan pekerjaannya. Berdasarkan uraian diatas, maka dapat disimpulkan bahwa kepuasan kerja adalah merupakan suatu cara pandang seseorang terhadap pekerjaannya yang bersifat positif. Seorang karyawan akan merasa puas terhadap pekerjaannya bergantung pada cara mempersepsikan adanya kesesuaian antara keinginankeinginan dengan hasil yang didapatnya.seorang dengan tingkat kepuasan kerja yang tinggi akan memiliki perasaan-perasaan positif tentang pekerjaan tersebut dan akan diwujudkan dalam bentuk cara kerja dan hasil kerja yang baik.

\section{Kerangka Pemikiran}

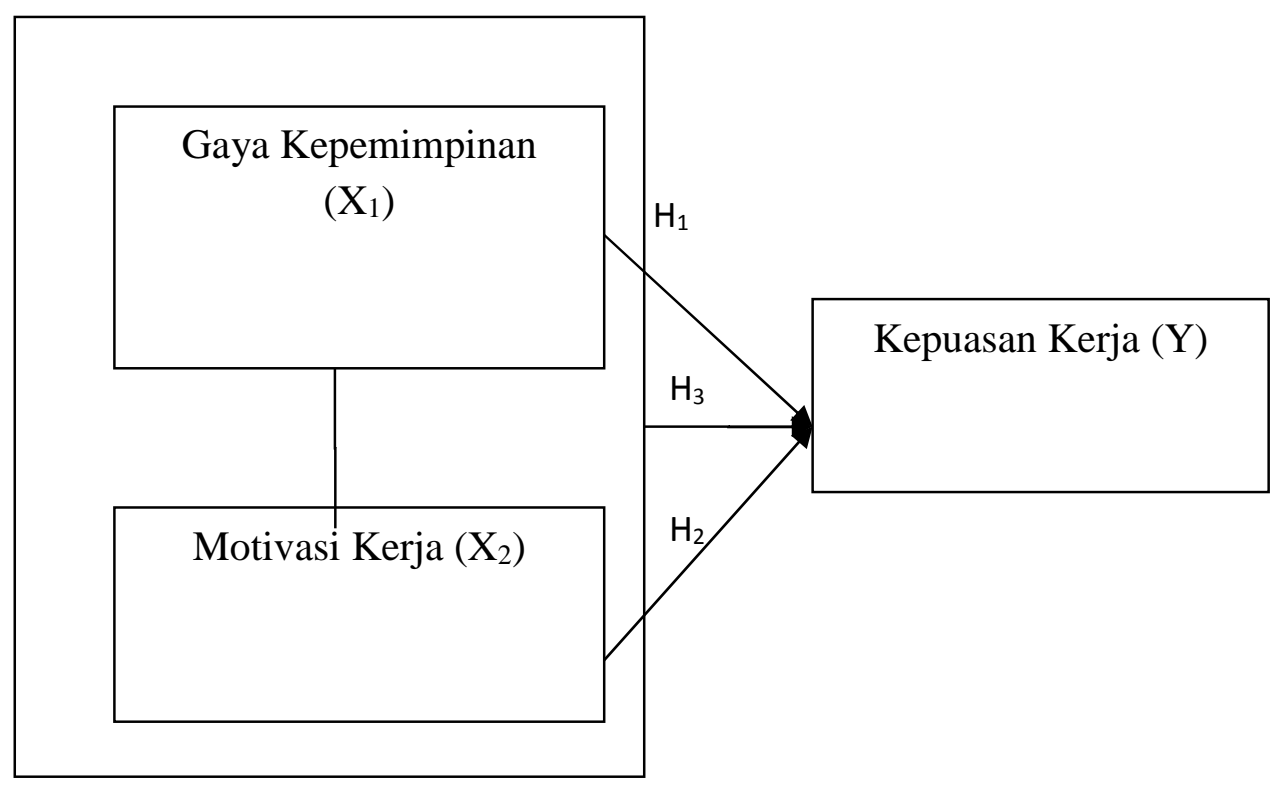

Gambar 1. Rerangka Pemikiran

Sumber: Ditulis oleh penulis

Variabel $\mathrm{X}_{1} \quad=$ Gaya Kepemimpinan (Variabel Independent)

Variabel $\mathrm{X}_{2}=$ Motivasi Kerja (Variabel Independent)

Variabel Y = Kepuasan Kerja (Variabel Dependent)

Hipotesis. Berdasarkan kerangka pemikiran di atas, maka hipotesis dalam penelitian ini, sebagai berikut:

$\mathrm{H}_{1}$ : Terdapat pengaruh yang signifikan antara gaya kepemimpinan terhadap kepuasan kerja karyawan. 
$\mathrm{H}_{2}$ : Terdapat pengaruh yang signifikan antara motivasi kerja terhadap kepuasan kerja karyawan.

H3 : Terdapat pengaruh yang signifikan antara gaya kepemimpinan dan motivasi kerja secara bersama-sama terhadap kepuasan kerja karyawan.

\section{METODE}

Populasi dan Metode Pemilihan Sampel. Objek penelitian terdiri atas variabel yang akan diteliti, yaitu variabel gaya kepemimpinan, motivasi sebagai variabel bebas (independent variable). Sedangkan kepuasan kerja sebagai variabel terikat (dependent variable).

Populasi dan Teknik Pemilihan Sampel. Populasi dalam penelitian ini menurut jenisnya merupakan populasi yang terbatas dan menurut sifatnya merupakan populasi yang homogen. Populasi dalam penelitian ini adalah karyawan PT Inovasi Teknologi yang berjumlah 75 orang.

Penelitian ini menarik sampel dengan metode atau teknik simple random sampling (teknik sampel sederhana), yaitu suatu cara pemilihan sejumlah elemen populasi untuk menjadi anggota sampel yang dilakukan sedemikian rupa sehingga setiap elemen mendapat kesempatan yang sama untuk dipilih menjadi anggota sampel. Cara ini dilakukan karena jumlah elemen dalam populasi diketahui dan relatif homogen. Dalam penelitian ini jumlah sampel sebanyak 75 responden.

Teknik Analisis Data. Pertama. Uji Asumsi Klasik. Sebelum dilakukan pengujian hipotesis menggunaan regresi linear berganda, terlebih dahulu dilakukan pengujian asumsi klasik. Tujuan dari pengujian asumsi klasik adalah agar dapat menghasilkan nilai parameter yang baik sehingga hasil penelitian dapat lebih akurat. Pengujian gejala penyimpangan dari asumsi klasik perlu dilakukan untuk mengetahui sifat dari data sehingga dapat ditentukan jenis uji yang tepat untuk menganalisis hubungan atara variabel-variabel yang diteliti. Persyaratan asumsi klasik yang harus dipenuhi dalam analisis linear ganda adalah bahwa residual harus berdistribusi normal, nonmultikolinearitas antara variabel independen, teijadi homokedastisitas, dan yang terakhir tidak terdapat otokolerasi.

a. Uji Normalitas (Normality). Uji normalitas bertujuan untuk mengetahui apakah nilai residual memenuhi asumsi normalitas. Uji normalitas dilakukan dengan melihat penyebaran data atau titik pada sumbu diagonal dari grafik pengujian normalitas (Normal Probability P-P Plot). Apabila data menyebar di sekitar garis diagonal dan mengikuti arah garis diagonal, maka model regresi memenuhi asumsi normalitas. Sedangkan, apabila data menyebar jauh dari garis diagonal dan tidak mengikuti arah garis diagonal, maka model regresi tidak memenuhi asumsi normalitas.

b. Uji Multikolinearitas (Multicollinearity). Uji multikolinearitas bertujuan untuk mengetahui apakah ada kolerasi antara variabel-variabel bebas yang diajukan dalam model regresi. Uji multikolinearitas dilakukan dengan melihat VIF (Variance Inflation Factor) yang dihasilkan melalui pengolaan data SPSS. Dasar pengambilan keputusannya adalah: (1) apabila nilai VIF kurang dari 10, maka dalam model regresi tidak terdapat masalah multikolinearitas; (2) apabila VIF lebih dari 10, maka salah satu variabel beban harus dikeluarkan dari model regresi. 
c. Uji Heteroskedastisitas. Uji heteroskedastisitas bertujuan untuk mengetahui apakah dalam model regresi terdapat perbedaan varians dari satu pengamatan ke pengamatan lain. Uji heteroskedastisitas dilakukan dengan melihat ada atau tidak adanya pola tertentu pada grafik, di mana pada sumbu $\mathrm{X}$ adalah prediksi variabel dependen dan sumbu Y adalah residual (Y prediksi - Y sesungguhnya) yang telah distandarisasi. Dasar pengambilan keputusan uji heteroskedastisitas untuk menguji apakah dalam model regresi terjadi ketidaksamaan variansi dari residual suatu pengamatan dengan pengamatan lainnya. Deteksi adanya heteroskedastisitas, yaitu dengan mengunakan scatterplot. Jika ada pola tertentu, seperti titik yang membentuk suatu pola yang teratur (bergelombang, melebar, kemudian menyempit) atau titik tersebut mengumpul di suatu sisi berarti terjadi heteroskedastisitas.

Analisis Regresi Ganda. Digunakan dalam penelitian ini untuk mengetahui hubungan variabel gaya kepemimpinan (X1) dan variabel motivasi (X2) dengan variabel kepuasan kerja (Y). Dimana rumusnya adalah sebagai berikut:

Sumber : (Djarwanto PS, 2003:310)

$$
\mathrm{Y}=\mathrm{a}+\mathrm{b}_{1} \mathrm{X}_{2}+\mathrm{b}_{2} \mathrm{X}_{2}
$$

Dimana: Y : Variable dependen (kepuasan kerja); a : Nilai intersep (konstanta); bi-b2 : Koefisien regresi linier; $\mathrm{X}_{1}$ : Variabel independen (gaya kepemimpinan); $\mathrm{X}_{2}:$ Variabel Independen (motivasi kerja)

Uji R Square. Pengujian $R$-Square bertujuan untuk mengukur besarnya porposi atau persentase dari jumlah variansi dari variabel dependen atau untuk mengukur sumbangan dari variabel independen terhadap variabel dependen. Nilai $R$ yang kecil berarti kemampuan variabel-variabel independen dalam menjelaskan variansi variabel dependen amat terbatas, sedangkan nilai yang besarnya (mendekati 1) berarti variabel-variabel independen memberikan hamper semua informasi yang dibutuhkan untuk memprediksi variansi variabel dependen.

Pengujian Hipotesis Penelitian. Setelah persamaan regresi ditemukan, maka tahap berikutnya adalah melakukan pengujian terhadap hipotesis penelitian untuk mengetahui apakah terdapat pengaruh variabel gaya kepemimpinan dan motivasi kerja (independen) terhadap variabel kepuasan kerja (dependen). Pengujian hipotesis tersebut dilakukan uji statistik yaitu menggunakan uji F (secara keseluruhan) dan uji t (secara parsial).

Uji F. Uji ini digunakan untuk mengetahui apakah variabel independen secara bersamasama berpengaruh secara signifikan terhadap variabel dependen. Pengujian secara simultan ini merupakan pengujian satu arah dengan menggunakan tingkat keyakinan $95 \%$. Ho diterima jika $\mathrm{F}$ hitung ^ $\mathrm{F}$ tabel sedangkan Ho ditolak jika $\mathrm{F}$ hitung > F tabel. Langkahlangkah pengujian nya adalah sebagai berikut: (a) Merumuskan hipotesis (merumuskan Ho dan $\mathrm{Ha}$ );(b) Menentukan nilai a (dalam penelitian ini ditentukan a $=5 \%$ ); (c) Membandingkan nilai signifikan dengan nilai $\boldsymbol{a}$;

Uji t. Uji t digunakan untuk mengetahui variabel independen mana yang paling berperan terhadap variabel dependen. 


\section{HASIL DAN PEMBAHASAN}

Uji Normalitas. Uji normalitas dilakukan dengan melihat penyebaran data atau tidak pada sumbu diagonal dari grafik pengujian normalitas (Normal Probability P-P Plot).

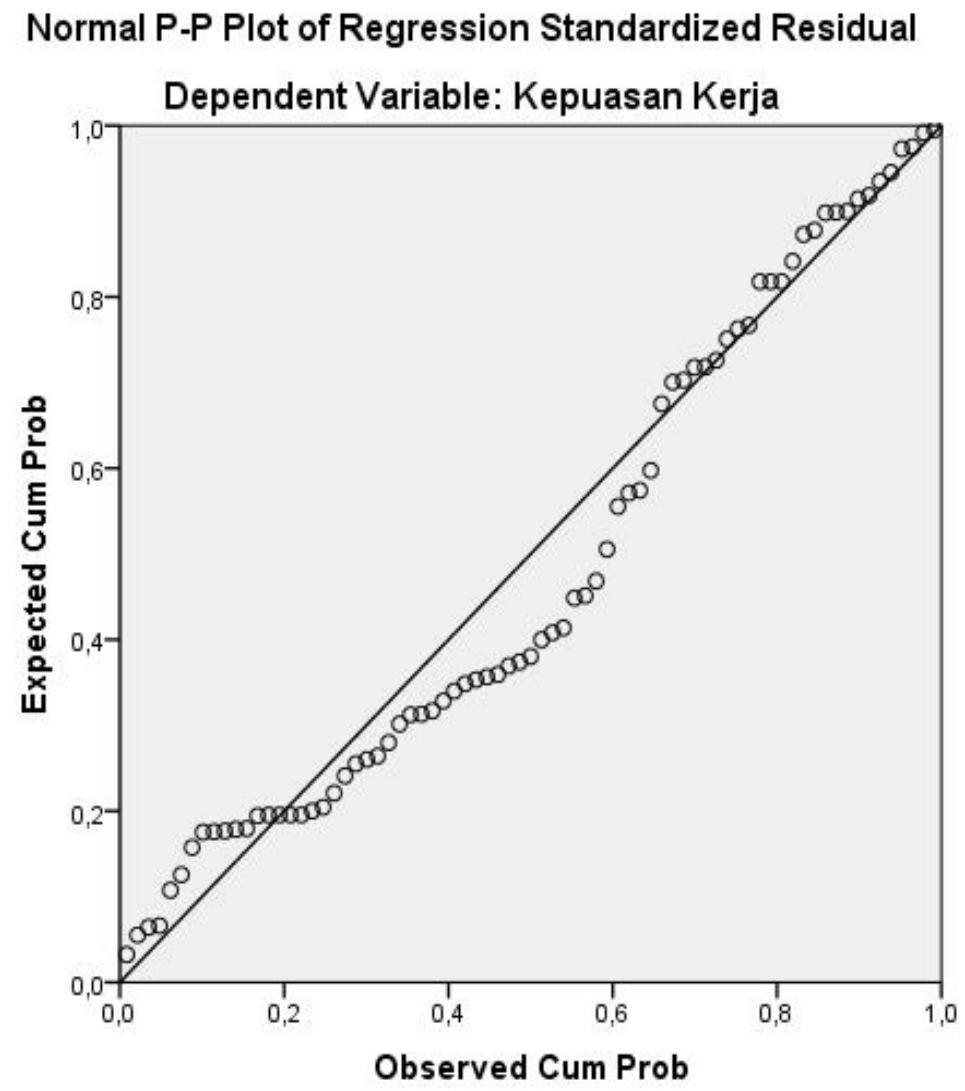

Gambar 2. Diagram Normal Probability

Dari hasil uji asumsi normalitas melalui Normal Probability P-P Plot diketahui bahwa data menyebar di sekitar garis diagonal dan mengikuti arah garis diagonal, maka model regresi tersebut memenuhi asumsi normal.

Uji Multikolinearitas. Keberadaan multikolinearitas diidentifikasikan melalui besaran nilai VIF (Variance Inflation Factor). Jika VIF kurang dari 10, maka dalam model regresi tidak terdapat masalah multikolinearitas.

Tabel 1. Uji Multikolinearitas

\begin{tabular}{|c|c|c|}
\hline \multirow{2}{*}{\multicolumn{2}{|c|}{ Model }} & Colinearity Statistics \\
\hline & & VIF \\
\hline \multicolumn{3}{|c|}{$1 \quad$ (Constant) } \\
\hline \multicolumn{2}{|r|}{ Gaya Kepemimpinan } & 1.551 \\
\hline & Motivasi & 1.551 \\
\hline
\end{tabular}


Pada Tabel 1 di atas diketahui VIF yang diperoleh masing-masing variabel kurang dari 10, maka dalam model regresi tidak terdapat masalah multikolinearitas.

\section{Uji Asumsi Heteroskedastisitas melalui Scatter Plot}

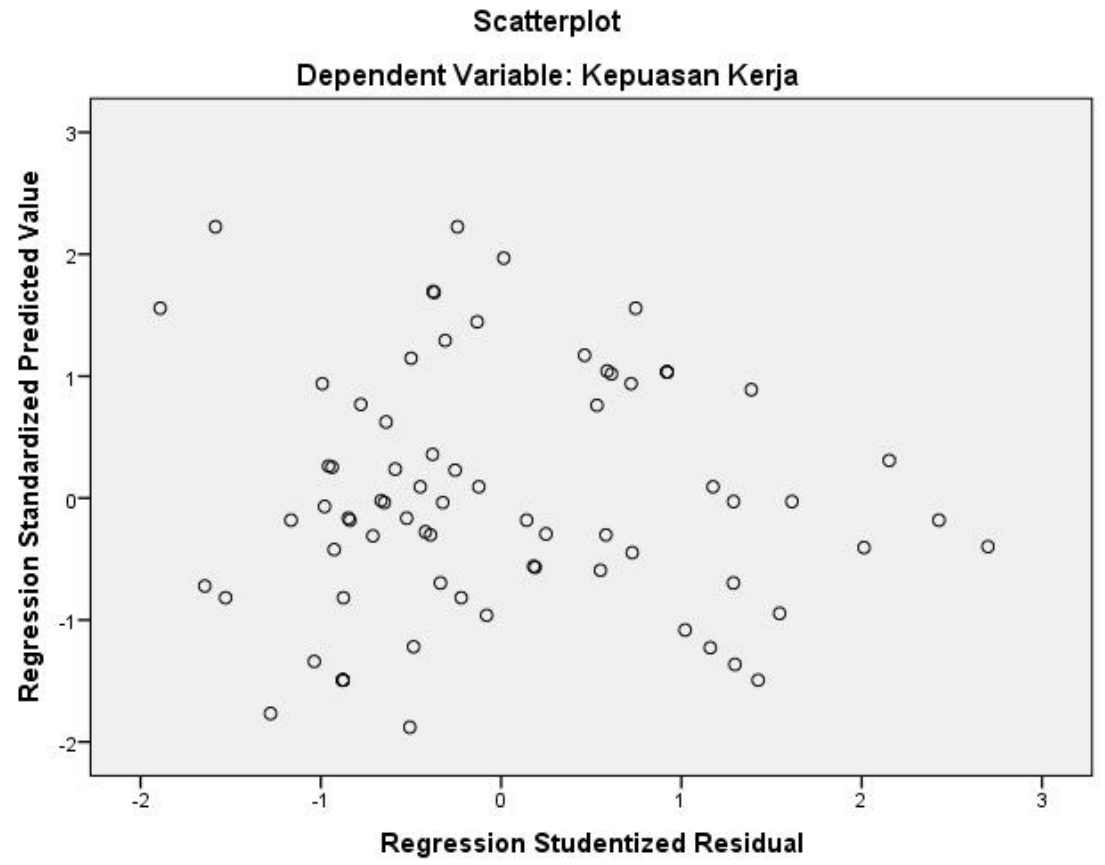

Gambar 3. Diagram Penar (Scatter Plot)

Dari hasil uji asumsi heteroskedastisitas melalui scatter plot dapat dilihat bahwa titik-titik menyebar di atas dan bawah angka nol dari sumbu Y, maka model regresi ini memiliki kesamaan varians atau tidak terjadi heteroskedastisitas.

Analisis Regresi Ganda. Analisis regresi ganda digunakan untuk mengetahui pengaruh variabel independen terhadap perubahan variabel dependen. Dalam hal ini variabel independennya adalah kepemimpinan dan kompensasi, sedangkan variabel dependennya adalah motivasi kerja.

Tabel 2. Analisis Regresi Ganda

\begin{tabular}{cccc}
\hline \multirow{2}{*}{ Model } & \multicolumn{2}{c}{ Unstandardized Coefficients } & $\begin{array}{c}\text { Standardized } \\
\text { Coefficients }\end{array}$ \\
\cline { 2 - 4 } & $\mathrm{B}$ & Std. Error & Beta \\
\hline 1. (Constant) & 7.085 & 2.580 & 0.381 \\
$\begin{array}{c}\text { Gaya } \\
\text { Kepemimpinan }\end{array}$ & 0.383 & 0.106 & 0.399 \\
motivasi & 0.407 & 0.108 & \\
\hline
\end{tabular}


Berdasarkan Tabel 2 dapat dirumuskan persamaan regresi sebagai berikut: $\mathrm{RI}=6,333+$ $0.383 \mathrm{Kep}+0,407$ mot. Penjelasan dari persamaan regresi tersebut adalah sebagai berikut: (1) Jika semua dimensi kepemimpinan dan motivasi $=0$ maka RI sebesar 7,085; (2) Jika terjadi perubahan gaya kepemimpinan sebesar 1 satuan, maka RI akan mengalami perubahan sebesar 0,383 satuan; (3) Jika terjadi perubahan motivasi sebesar 1 satuan, maka RI akan mengalami perubahan sebesar 0,407.

Selain itu, dari persamaan tersebut juga diketahui bahwa nilai koefisien regresi (B) yang terbesar adalah motivasi sebesar 0,407. Kemudian diikuti gaya kepemimpinan sebesar 0,383 .

\section{Uji F}

Tabel 3. Uji Koefisien Regresi Ganda Secara Simultan dengan Uji F

\begin{tabular}{llrrrrr}
\hline & Model & $\begin{array}{l}\text { Sum of } \\
\text { Square }\end{array}$ & df & \multicolumn{1}{c}{$\begin{array}{c}\text { Mean } \\
\text { Square }\end{array}$} & F & Sig \\
\hline 1. & Regression & 653.829 & 2 & 326.915 & 33.852 & $0.000^{\mathrm{b}}$ \\
& Residual & 659.318 & 72 & 9.657 & & \\
Total & 1349.147 & 74 & & & \\
\hline
\end{tabular}

Berdasarkan Tabel 3 diperoleh tingkat signifikasi sebesar 0,000 dimana angka tersebut lebih kecil dari 0.05 , hal ini berarti paling sedikit terdapat satu variabel independen yang mempengaruhi motivasi kerja, karena angka signifikasi lebih kecil dari $\alpha=5 \%$. adapun perumusan hipotesis sebagai berikut :

$\mathrm{H}_{3}$ : Terdapat pengaruh kepemimpinan dan motivasi secara bersama-sama terhadap kepuasan kerja karyawan di PT Inovasi Teknologi.

Pengujian Hipotesis. Untuk menjawab perumusan masalah penelitian mengenai pengaruh gaya kepemimpinan dan motivasi terhadap kepuasan kerja maka hipotesis penelitian harus diuji terlebih dahulu. Penelitian ini menggunakan SPSS versi 20 dalam melakukan pengujian hipotesis. Pengujian hipotesis dilakukan secara parsial dan simultan. Pengujian secara parsial dilakukan dengan tujuan untuk melihat pengaruh tiap variabel independen terhadap variabel dependen, sedangkan pengujian secara simultan dilakukan dengan tujuan melihat pengaruh seluruh variabel dependen secara simultan terhadap variabel dependen. Berikut adalah output SPSS mengenai pengujian hipotesis yang dilakukan.

Tabel 4. Uji Koefisien Regresi Sederhana dengan Uji-t coefficients

\begin{tabular}{ccccccc}
\hline & \multicolumn{2}{c}{$\begin{array}{c}\text { Unstandardized } \\
\text { Coefficients }\end{array}$} & $\begin{array}{c}\text { Standardized } \\
\text { Coefficients }\end{array}$ & & \\
\cline { 2 - 5 } Model & $\mathrm{B}$ & Std. Error & Beta & $\mathrm{T}$ & Sig. \\
\hline & 7.085 & 2.580 & & 2.746 & .008 \\
1. (Constant) & .383 & .106 & .381 & 3.612 & .001 \\
Gaya Kepemimpinan & .407 & .108 & .399 & 3.783 & .000 \\
Kepuasan kerja & & & & & & \\
\hline
\end{tabular}

Uji Hipotesis Pertama. Adapun perumusan hipotesis yang pertama adalah sebagai berikut: 
$\mathrm{H}_{1}$ : terdapat pengaruh yang signifikan dan positif antara gaya kepemimpinan terhadap Kepuasan kerja karyawan PT Inovasi Teknologi.

Dari Tabel 4 dapat dilihat bahwa variabel Gaya kepemimpinan terhadap Kepuasan kerja memiliki tingkat signifikansi sebesar 0,000 . Hal ini berarti gaya kepemimpinan secara parsial berpengaruh secara positif terhadap Kepuasan kerja karena angka signifikansi lebih kecil dari $\alpha=5 \%$. Jadi, dapat disimpulkan bahwa $\mathrm{H}_{1}$ tidak ditolak.

Uji Hipotesis Kedua. Adapun perumusan hipotesis yang kedua adalah sebagai berikut: $\mathrm{H}_{2}$ : terdapat pengaruh yang signifikan dan positif antara Motivasi terhadap Kepuasan kerja karyawan PT Inovasi Teknologi. Dari Tabel 4 dapat dilihat bahwa variabel Motivasi terhadap Kepuasan kerja memiliki tingkat signifikansi sebesar 0,000. Hal ini berarti motivasi secara parsial berpengaruh secara positif terhadap kepuasan kerja karena angka signifikansi lebih kecil dari $\alpha=5 \%$. Jadi, dapat disimpulkan bahwan $\mathrm{H}_{2}$ tidak ditolak.

Pengujian $\mathbf{R}$-Square $\left(\mathbf{R}^{2}\right)$. R-Square untuk mengetahui kontribusi dari variabel-variabel independen terhadap naik turunnya variabel dependen. Berikut ini adalah hasil perhitungan menggunakan SPSS:

Tabel 5. Pengujuan R-Square $\left(\mathrm{R}^{2}\right)$

\begin{tabular}{ccccc}
\hline Model & $\mathrm{R}$ & R Square & Adjusted R Square & $\begin{array}{c}\text { Std. Error of } \\
\text { the Estimate }\end{array}$ \\
\hline 1 & $.696^{\mathrm{a}}$ & .485 & .470 & 3.108 \\
\hline
\end{tabular}

Dari hasil analisis di atas, dapat diketahui nilai R-Square sebesar 0,485 yang berarti 48,5\% variabel dependen kepuasan kerja dapat dijelaskan oleh gaya kepemimpinan dan motivasi, sedangkan sisanya $(100 \%-48,5 \%)=51.5 \%$ dijelaskan oleh variabel-variabel lainnya.

Pengaruh Gaya Kepemimpinan Terhadap Kepuasan Kerja Karyawan pada PT Inovasi Teknologi. Menurut Nawawi (2008:229) kepemimpinan adalah suatu kemampuan untuk menggerakkan atau memotivasi anggota organisasi agar secara serentak melakukan kegiatan yang sama dan terarah dalam pencapaian tujuannya. Kepemimpinan juga merupakan aspek penting dalam mengelola organisasi karena kemampuan memimpin merupakan salah satu kunci untuk menjadi manajer yang baik. Sebaliknya para manajer perlu berusaha untuk menjalankan dasar-dasar kepemimpinan agar menjadi pemimpin yang efektif (Nawawi, 2008: 230).

Penelitian oleh I G.A Dwi Perbawa Nugraha (2011), dengan judul "Pengaruh Gaya Kepemimpinan dan Motivasi Kerja Terhadap Kepuasan Kerja Anggota Detasemen C Satuan III Pelopor Korps Brimob Polri “ hasil penelitian ini memberikan gambaran bahwa semakin baik gaya kepemimpinan yang ditunjukkan dan diterapkan oleh seorang pemimpin organinasi,maka akan berpengaruh positif terhadap kepuasan kerja.

Uji $\mathrm{T}$ pengaruh kepemimpinan terhadap kepuasan kerja menghasilkan $\mathrm{t}$ hitung $=$ 3.612 dengan nilai signifikansi $=0.001<0.05$. Berdasarkan hasil tersebut maka $\mathrm{H} 0$ ditolak dan $\mathrm{H} 1$ diterima, dapat disimpulkan bahwa gaya kepemimpinan berpengaruh terhadap kepuasan kerja karyawan pada PT Inovasi Teknologi. 
Pengaruh Motivasi Kerja Terhadap Kepuasan Kerja Karyawan pada PT Inovasi Teknologi. Motivasi menurut Anoraga (2005) dalam Purwati (2009) adalah kebutuhan yang mendorong perbuatan untuk suatu tujuan tertentu. Jadi motivasi kerja adalah sesuatu yang menimbulkan semangat atau dorongan kerja. Sedangkan menurut Robbins (2002:225) adalah kesediaan melakukan usaha tingkat tinggi guna mencapai sasaran organisasi, yang dikondisikan oleh kemampuan usaha tersebut memuaskan kebutuhan sejumlah individu.

Penelitian oleh I G.A Dwi Perbawa Nugraha (2011), dengan judul "Pengaruh Gaya Kepemimpinan dan Motivasi Kerja Terhadap Kepuasan Kerja Anggota Detasemen C Satuan III Pelopor Korps Brimob Polri “ hasil penelitian ini menunjukkan bahwa motivasi kerja berpengaruh secara positif terhadap kepuasan kerja

Uji $\mathrm{T}$ pengaruh motivasi kerja terhadap kepuasan kerja menghasilkan $\mathrm{t}$ hitung $=$ 3.783 dengan nilai signifikansi $=0.000<0.05$. Berdasarkan hasil tersebut maka H0 ditolak dan H1 diterima, dapat disimpulkan bahwa motivasi kerja berpengaruh terhadap kepuasan kerja karyawan pada PT Inovasi Teknologi.

Pengaruh Gaya Kepemimpinan dan Motivasi Kerja Secara Bersama-sama Terhadap Kepuasan Kerja Karyawan Pada PT Inovasi Teknologi. Dole dan Schroeder (2001) dalam koesmono (2005), mengemukakan bahwa kepuasan kerja dapat didefinisikan sebagai perasaan dan reaksi individu terhadap lingkungan pekerjaannya. Lebih lanjut Koesmono (2005) mengemukakan bahwa kepuasan kerja merupakan penilaian, perasaan atau sikap seseorang atau karyawan terhadap pekerjaan atau sikap seseorang atau karyawan terhadap pekerjaannya dan berhubungan dengan lingkungan kerja, jenis pekerjaan, kompensasi, hubungan antar teman kerja, hubungan sosial ditempat kerja dan sebagainya.

Penelitian oleh I G.A Dwi Perbawa Nugraha (2011), dengan judul "Pengaruh Gaya Kepemimpinan dan Motivasi Kerja Terhadap Kepuasan Kerja Anggota Detasemen C Satuan III Pelopor Korps Brimob Polri“ hasil penelitian ini menunjukkan bahwa gaya kepemimpinan dan motivasi kerja berpengaruh secara bersama-sama terhadap kepuasan kerja.

Uji F pengaruh gaya kepemimpinan dan motivasi kerja terhadap kepuasan karyawan menghasilkan $F=33.852$. Diperoleh tingkat signifikansi sebesar 0.000 dimana angka tersebut lebih kecil dari 0.05 . Hal ini berarti paling sedikit terdapat satu variabel independen yang mempengaruhi kepuasan kerja, karena angka signifikansi lebih kecil dari $\alpha=5 \%$. Dapat diketahui nilai $R$-Square sebesar 0,485 yang berarti $48,5 \%$ variabel dependen kepuasan kerja dapat dijelaskan oleh gaya kepemimpinan dan motivasi, sedangkan sisanya $(100 \%-48,5 \%)=51.5 \%$ dijelaskan oleh variabel-variabel lainnya.

Berdasarkan hasil analisis data maka hasil penelitian ini terkait pengaruh gaya kepemimpinan dan motivasi terhadap kepuasan kerja sesuai dengan penelitinan yang dilakukan oleh I G.A Dwi Perbawa Nugraha (2011) yang berjudul "Pengaruh Gaya Kepemimpinan dan Motivasi Kerja Terhadap Kepuasan Kerja Anggota Detasemen C Satuan III Pelopor Korps Brimob Polri." yang menyatakan bahwa terdapat pengaruh yang positif gaya kepemimpinan dan motivasi kerja terhadap kepuasan kerja.

\section{PENUTUP}

Simpulan. Berdasarkan penelitian dan pembahasan yang telah dilakukan tentang pengaruh kepemimpinan dan kompensasi terhadap motivasi kerja karyawan di PT Inovasi 
Teknologi, dengan menggunakan uji $\mathrm{F}$ dan ujiT maka kesimpulan yang dapat ditarik adalah sebagai berikut: (1) Terdapat pengaruh yang signifikan dan positif antara gaya kepemimpinan terhadap kepuasan kerja secara parsial pada karyawan PT Inovasi Teknologi; (2) Terdapat pengaruh yang signifikan dan positif antara motivasi kerja terhadap kepuasan kerja secara parsial pada karyawan PT Inovasi Teknologi; (3) Terdapat pengaruh yang signifikan dan positif antara gaya kepemimpinan dan motivasi kerja secara bersama-sama terhadap kepuasan kerja karyawan di PT Inovasi Teknologi.

Saran. Terkait dengan hasil penelitian ini, peneliti akan memberikan beberapa saran yang sekiranya dapat bermanfaat bagi perusahaan dan bagi peneliti lain, yaitu sebagai berikut: (1) Bagi perusahaan, Peneliti menyarankan untuk mempertahankan gaya kepemimimpinan yang sudah diterapkan saat ini dan mempertahankan motivasi yang sudah dijalankan;(2) Bagi peneliti lain, disarankan untuk melakukan penambahan variabel lainnya yang dapat mempengaruhi motivasi kerja, seperti faktor keamanan, keselamatan dan lain-lain.

\section{DAFTAR RUJUKAN}

Agung wijaya. (2008) Pengaruh Motivasi Kerja, Kepuasan Kerja, Dan Gaya Kepemimpinan Terhadap Kinerja Pegawai Di PT. Nina Album Semarang, Universitas Katolik Soegijapranata, Semarang.

Dubrin Andrew J., (2005) Leadership (Terjemahan), Edisi Kedua, Prenada Media,Jakarta.

Djarwanto, PS. (2003) Mengenal Beberapa Uji Statistik dalam Penelitian. Edisi Kedua, Penerbit Libertu, Yogyakarta.

Elfanda Ajeng Novita. (2013) Pengaruh Gaya Kepemimpinan Dan Motivasi Kerja Terhadap Kepuasan Kerja Karyawan Pada Bagian Ticketing Di PT. Haryono Tours And Travel Surabaya, Universitas Negeri Surabaya.

Fisla Wirda dan Tuti Azra, (2012) Pengaruh Gaya Kepemimpinan Situasional Dan Motivasi Kerja Terhadap Kepuasan Kerja Karyawan Politeknik Negeri Padang, Politeknik Negeri Padang.

Gibson. (2001) Organisasi perilaku-struktur-proses,Terjemahan, Edisi V.Jakarta: Penerbit Erlangga.

Hadari Nawawi, (2008) Manajemen Sumber Daya Manusia: Untuk Bisnis Yang Kompetitif, gadjah mada university press.

Hasibuan, M. (2003). Manajemen Sumber Daya Manusia. Jakarta.PT Bumi Aksara.

I G.A Dwi Perbawa Nugraha, (2011) Pengaruh Gaya Kepemimpinan Dan Motivasi Kerja

Terhadap Kepuasan Kerja Anggota Detasemen C Satuan III Pelopor Korps Brimob Polri,Fakultas Pasca Sarjana Program Studi Kajian Ilmu Kepolisian Kekhususan Administrasi Kepolisian, Universitas Indonesia,Jakarta.

Indah Handayani (2012) Pengaruh Gaya Kepimpinan, Motivasi Dan Kepuasan Kerja Terhadap Kinerja Menurut Persepsi Pegawai Negeri Sipil Di Lingkungan Sekretariat Daerah Provinsi Kepulauan Riau, Universitas Terbuka, Jakarta.

Khaerul Umam. (2010) Perilaku organisasi. Penerbit CV Pustaka Setia.

Koesmono H. Teman, (2005) Pengaruh Budaya Organisasi terhadap Motivasi dan Kepuasan Kerja serta Kinerja Karyawan pada SubSektor Industri Pengolahan Kayu Ekspor diJawa Timur, Disertasi Universitas Airlangga, Surabaya.

Mulyadi, Deddi. dan Veithzal Rivai. (2009) Kepemimpinan dan Perilaku Organisasi. Jakarta: Rajawali Pers.

Nimran Umar, (2004) Perilaku Organisasi, Cetakan Ketiga, CV. Citra Media, Surabaya. 
Rachmad Bahagia., (2004) Pengaruh Kepemimpinan dan Motivasi Terhadap Kepuasan Kerja Pegawai PDAM Tirtanadi Kantor Pusat Medan, Universitas Sumatra Utara.

Robbins Stephen P., (2002) Essentials of Organizational Behavior (Terjemahan), Edisi Kelima, Penerbit Erlangga, Jakarta.

Siagian Sondang P., (2002). Kiat Meningkatkan Produktivitas Kerja, Cetakan Pertama, PT.Rineka Cipta, Jakarta.

Suprihanto John, Harsiwi Th. Agung M., HadiPrakosa, (2003) Perilaku Organisasional,Cetakan Pertama, Bagian Penerbitan Sekolah Tinggi Ilmu Ekonomi, Yogyakarta.

Suwastini., (2011) Pengaruh Kepuasan Kerja, Motivasi Kerja, Gaya Kepemimpinan Dan Budaya Kerja Terhadap Kinerja Karyawan Rumah Sakit Royal Progress Jakarta, Universitas Terbuka, Jakarta.

Yasin Azis, (2001) Kepemimpinan dalam Pengembangan Organisasi, Jurnal Lintasan Ekonomi Fakultas Ekonomi Universitas Brawijaya Malang, Volume 18 Nomor 1, Malang. 